\title{
IMPLEMENTASI KEBIJAKAN PENGEMBANGAN PARIWISATA BERBASIS PEMBERDAYAAN MASYARAKAT
}

\author{
Kariaman Sinaga'; M. Amri Nasution²; Ayu Trisna Dewi ${ }^{3}$ \\ Universitas Dharmawangsa \\ kariamansinaga@dharmawangsa.ac.id ${ }^{1}$; amrinasution@dharmawangsa.ac.id²; \\ ayutrisna@dharmawangsa.ac.id ${ }^{3}$
}

\begin{abstract}
ABSTRAK
Tujuan penelitian ini adalah untuk mengetahui bagaimana implementasi pengembangan pariwisata di Kecamatan Pantai Cermin. Metode penelitian ini adalah deskriptif kualitatif. Pengembangan pariwisata belum berjalan secara maksimal dikarenakan tidak menerapkan prinsip-prinsip implementasi. Pemberdayaan masyarakat yang menjadi upaya prioritas dalam mendukung efektifitas dan efisiensi suatu program kurang sesuai dengan kondisi masyarakat. Melalui penelitian ditemukan bahwa antara pemerintah Kabupaten Serdang Bedagai dengan Pemerintah Kecamatan Pantai Cermin kurang berkoordinasi dan komunikasi dalam proses implementasi dan dapat diduga adanya disposis yang salah sesuai dengan prinsip-prinsip implementasi. Hal ini dapat diketahui melalui kurangnya sumberdaya manusia yang memahami dalam mendukung suatu program pembangunan melalui implementasi suatu program. Sebagai novelty dalam penelitian bahwa penetapan kebijakan yang dilakukan telah mengalami kesalahan dari awal dengan tidak menyesuaikan dengan kondisi masyarakat dan adanya ego sektoral dalam menjalankan suatu implementasi program dikalangan pemerintah Kabupaten Serdang Bedagai dengan Pemerintah Kecamatan Pantai Cermin. Solusi yang ditawarkan dengan adanya perbedaan kondisi social menuntut pemberdayaan masyarakat dalam bidang pertanian untuk dikembangkan sejalan dengan kepariwsataan, sedangkan kordinasi, komunikasi, dan disposisi yang diharapkan dapat dilakukan dengan membentuk bagian atau bidang pengembangan pariwisata di tingkat kecamatan khususnya di Kecamatan Pantai Cermin.
\end{abstract}

Kata Kunci: Implementasi, Pengembangan Pariwisata, Pemberdayaan Masyarakat

\begin{abstract}
The implementation of tourism development in Pantai Cermin District has not been running optimally because in its implementation it has not applied the principles of implementation. Likewise, community empowerment which is a priority effort in supporting the effectiveness and efficiency of a program is not in accordance with the conditions of the community. The research was conducted with a descriptive qualitative approach through interviews with the District government and with business actors in the Pantai Cermin District to find out the implementation process in tourism development. Through this research it was found that between the Serdang Bedagai Regency government and the Pantai Cermin District Government lack coordination and communication in the implementation process and it can be suspected that the disposition is wrong in accordance with the principles of implementation. This can be seen through the lack of human resources who understand in supporting a development program through the implementation of a
\end{abstract}


PUBLIK: Jurnal Manajemen Sumber Daya Manusia, Adminsitrasi dan Pelayanan Publik Sekolah Tinggi Ilmu Administrasi Bina Taruna Gorontalo Volume VIII Nomor 1, 2021

program. As novelty in the research that the policy making has been wrong from the start by not adjusting to the conditions of the community and the existence of sectoral egos in carrying out a program implementation among the Serdang Bedagai Regency government and the Pantai Cermin District Government. The solutions offered by the existence of differences in social conditions require community empowerment in the agricultural sector to be developed in line with tourism, while the coordination, communication and disposition that are expected can be done by forming parts or fields of tourism development at the sub-district level, especially in Pantai Cermin District. Keywords: Implementation, Tourism Development, Community Empowerment

\section{PENDAHULUAN}

Implemetasi kebijakan merupakan bagian penting dalam menentukan keberhasilan suatu kebijakan baik di level nasional maupun level daerah. Oleh karenanya menjadi penting penelitian tentang implementasi suatu kebijakan untuk menjadi dasar dalam menentukan kebijakan selanjutnya. Kebijakan Pemerintah Kabupaten Serdang Bedagai menetapkan Kecamatan Pantai Cermin sebagai kecamatan yang pembangunannya berbasis pariwisata menjadi hal yang menarik untuk meneliti bagaimana implementasinya.

Penelitian terkait menyatakan bahwa kunjungan wisatawan ke Sumatera Utara sangat ditentukan oleh penilaian wisatawan itu sendiri terhadap transportasi, destinasi prasarana wisata, serta atribut lainnya (Silaban et al., 2017). Sedangkan pembahasan tentang kesiapan pemerintah daerah dalam menjalankan kebijakan berdasarkan aspek implementasi dan unsur pengembangan pariwisata menjadi hal yang penting untuk mendukung keberhasilan pengembangan pariwisata.

Melalui penelitian tentang implementasi kebijakan pembangunan yang dilakukan pemerintah daerah, diharapkan akan memberikan efektifitas suatu kebijakan yang telah ditetapkan. Terlebih pada kebijakan strategis atau kebijakan yang menyangkut pada masyarakat luas maka evaluasi atas implementasi kebijakan sangat dibutuhkan. Keterkaitan atau sinergitas dalam implementasi kebijakan pengembangan pariwisata antara pihak pemerintah, pihak swasta (pengusaha), dan masyarakat akan menjadi dasar untuk keberhasilan pengembangan suatu wilayah.

Kecamatan Pantai Cermin yang telah ditetapkan sebagai kecamatan yang berbasis pariwisata memiliki potensi wisata baik potensi wisata alami maupun potensi wisata buatan manusia. Dengan potensi yang dimiliki maka pemerintah Kabupaten Serdang Bedagai melakukan kebijakan pengembangan pariwisata yang harus melibatkan berbagai pihak agar tujuan yang dicapai dapat berjalan secara efektif dan efisien. Konsep keterlibatan berbagai pihak dalam menjalankan suatu kebijakan dikenal dengan konsep Good Governance yang 
telah dijalankan pemerintah namun tetap memerlukan evaluasi dalam implementasi kebijakannya.

Implementasi pengembangan pariwisata memerlukan penyesuaian dengan aspekaspek yang harus dipenuhi dalam pengembangan pariwisata itu sendiri. Sehingga diharapkan melalui implementasi kebijakan akan mendukung aspek pemberdayaan masyarakat. Konsep good governance memberikan peluang untuk meningkatkan pemberdayaan masyarakat sejalan dengan peningkatan pendapatan daerah dan kesejahteraan masyarakat. Hal ini akan memberikan pengaruh kuat terhadap peningkatan pendapatan daerah dan lapangan kerja di daerah (Rusyidi \& Fedryansah, 2019).

Potensi wisata yang dapat dikembangkan di Kecamatan Pantai Cermin meliputi wisata pantai dan juga wisata alam pertanian agar yang dapat menjadi tujuan wisata. Potensi wisata pantai telah didukung dengan tersedianya pondok-pondok istirahat yang dipersiapkan untuk menikmati pantai, permainan wahana air, taman bermain anak, maupun tempat berselfie sebagai bagian kegiatan fasilitas bagi wisatawan. Hal ini sesuai dengan kebijakan Pemerintah Kabupaten Serdang Bedagai yang menetapkan Kabupaten Pantai Cermin sebagai kecamatan yang berbasis pada wisata bahari.

Sebagai gambaran singkat Kecamatan Pantai Cermin yang terkait dengan pengembangan pariwisata juga memiliki potensi lain selain wisata pantai yang dapat diandalkan baik di tingkat regional maupun maupun secara internasional. Potensi yang dimaksud yaitu oleh-oleh yang merupakan hasil bumi dan kerajinan (handcraft) yang ada di Kecamatan Pantai Cermin sebagaimana tercantum pada tabel dibawah.

Gambar 1.1. Produk Khas Kecamatan Pantai Cermin

\begin{tabular}{|c|l|l|}
\hline No. & \multicolumn{1}{|c|}{ Nama Produk } & \multicolumn{1}{|c|}{ Pemasaran } \\
\hline 1. & Kelapa Pandan & Internasional \\
\hline 2. & Kain Temurun & Lokal \\
\hline 3. & Jambu Madu & Lokal \\
\hline
\end{tabular}

Sumber: Hasil wawancara dengan Ketua Bidang Pemberdayaan Masyarakat Kec. Pantai Cermin

Secara garis besar pembahasan penelitian tentang pengembangan pariwisata akan melihat 2 (dua) jenis pengembangan yang dilakukan pihak pemerintah Kecamatan Pantai Cermin yaitu: pengembangan pariwisata yang dilakukan terhadap pelaku usaha yang besifat tradisional dan pengembangan pariwisata yang dilakukan terhadap pelaku pariwisata yang bersifat profesional. Demikian pula menyangkut aspek-aspek implementasi yang menuntut 
adanya sinergitas antara pemerintah kabupaten dengan pemerintah kecamatan dalam hal koordinasi, komunikasi, maupun disposisi yang dijalankan.

Pembahasan tentang implementasi kebijakan yang dilakukan oleh Pemerintah Kabupaten Serdang Bedagai dengan Pemerintah Kecamatan Pantai Cermin dalam pelaksanaan pengembangan pariwisata. Sedangkan secara spesifik indikator implementasi kebijakan meliputi: a. Aspek Koordinasi b. Aspek Komunikasi c. Aspek Disposisi. Sedangkan variabel berikutnya adalah pengembangan pariwisata yang terdiri dari: a. Aspek Fasilitas, b. Aspek Transportasi, c. Aspek Atraksi, d. Aspek Promosi. Hal ini merupakan wujud tanggung jawab dari pemerintah daerah dalam upaya pembangunan atau pelaksanaan dari otonomi daerah yang tercantum dalam UU No. 32 Tahun 2004 Tentang Pelaksanaan Otonomi Daerah. (Hendrita, 2017)

Pengembangan pariwisata secara umum merupakan implementasi pengembangan pariwisata yang memiliki aspek-aspek yang harus dipenuhi baik yang dilaksanakan secara nasional maupun daerah. Aspek-aspek yang dimaksud meliputi: 1. Aspek Wisatawan; 2. Aspek Transportasi; 3. Aspek Promosi; 4. Aspek Atraksi Wisata; 5. Aspek Kuliner.

Potensi wisata yang dimiliki Kecamatan Pantai Cermin telah menjadi kebijakan pemerintah Kabupaten Serdang Bedagai dengan melakukan implementasi pengembangan pariwisata. Hal ini merupakan pembahasan yang diharapkan menjadi evaluasi atas suatu pelaksanaan kebijakan khususnya pengembangan pariwisata.

Secara kebijakan publik penelitian implementasi kebijakan pengembangan dalam pariwisata dapat dilihat melalui tiga garis besar pelaksanaannya yaitu: 1. Tugas Pelayanan; 2. Tugas Pembangunan; dan 3. Tugas Pemberdayaan.

Tugas-tugas pelayanan dilaksanakan sesuai dengan bagian yang juga terkait dengan implementasi suatu kebijakan yang dijalankan yang dalam hal ini merupakan pengembangan pariwisata. Beberapa program yang dimaksud merupakan program pembangunan yang dijalankan secara nasional, program pembangunan di tingkat provinsi, program pembangunan di tingkat kabupaten, maupun pembangunan yang dijalankan di tingkat kecamatan dan desa.

Tugas pembangunan yang dilakukan melalui pembangunan sarana fisik maupun nonfisik yang dilakukan baik yang dilakukan melalui program pembangunan secara nasional maupun berdasarkan program pembangunan daerah. Sedangkan program pemberdayaan merupakan program yang dilakukan dengan memanfaatkan pengenalan, penguatan, dan perlindungan terhadap potensi sumber daya masyarakat. Dalam hal ini penelitian yang dilakukan adalah berkaitan dengan pengembangan sektor pariwisata. 
Untuk mengetahui implementasi suatu kebijakan maka sangat diperlukan penelitian agar dapat mengetahui tentang prinsip-prinsip implementasi. Kemudian untuk melihat penerapan aspek pemberdayaan masyarakat sebagai paradigm pembangunan maka sangat diperlukan adanya penelitian khususnya tentang pengembangan suatu kawasan wisata.

\section{METODE PENELITIAN}

Penelitian ini akan dilaksanakan pada bulan Juli 2020 dan selesai pada bulan Desember 2020, sedangkan lokasi penelitian dilakukan di Kecamatan Pantai Cermin, Kabupaten Serdang Bedagai, Provinsi Sumatera Utara. Metode yang digunakan dalam penelitian ini adalah metode deskriptif kualitatif yaitu jenis penelitian yang berusaha menggambarkan objek atau subjek yang diteliti sesuai dengan apa adanya (alami) dengan tujuan menggambarkan secara sistematis fakta dan karakteristik objek yang diteliti secara tepat dan memahami setiap konteks fenomena secara keseluruhan. Penelitian ini dilakukan dengan metode deskriptif dengan pendekatan kualitatif. Creswell (2010), mengemukakan bahwa penelitian kualitatif merupakan metode-metode untuk mengeksplorasi dan memahami makna yang oleh sejumlah individu dan kelompok orang dianggap berasal dari masalah sosial atau kemanusiaan.

Proses penelitian kualitatif dilakukan dengan melibatkan upaya-upaya penting, seperti mengajukan pertanyaan-pertanyaan dan prosedur-prodeur mengumpulkan data yang spesifik, menganalisis data secara induktif mulai dari tema-tema yang khusus ke tema-tema yang umum, dan menafsirkan makna data. Sedangkan jenis penelitian ini adalah deskriptif yang menggambarkan realitas objek penelitian dan memberikan makna dari obyek yang diteliti. (Charmaz \& Thornberg, 2020) menyatakan bahwa penelitian ini juga mengungkapkan dan memahami sesuatu di balik fenomena yang baru diketahui.

Penelitian dilakukan hanya melihat bagaimana kordinasi, komunikasi, dan disposisi yang dilakukan antara pihak pemerintah, pihak swasta, dan pihak masyarakat dalam implementasi pengembangan pariwisata yang menyangkut pada wisatawan, transportasi, fasilitas wisata, dan atraksi wisata. Pembahasan akan melihat berdasarkan perspektif pemberdayaan masyarakat, perencanaan wilayah, dan kebijakan publik.

\section{HASIL PEMBAHASAN}

\section{Konsep Pengembangan Pariwisata}

Berdasarkan hasil penelitian, secara umum terdapat 2 (dua) jenis pengembangan pariwisata yang dilakukan di Kecamatan Pantai Cermin yaitu:

1. Pengembangan Pariwisata Tradisional.

Pengelolaan pariwisata secara tradisional dilakukan oleh kelompok masyarakat, atau dilakukan dengan swadaya masyarakat. Umumnya pengelolaan wisata secara tradisonal 
belum memiliki fasilitas wisata yang lengkap atau memadai karena sangat berkaitan dengan kesiapan anggaran dan sumber daya manusia yang dimiliki. Gambaran lainnya tentang pengelolaan pariwisata secara tradisional lebih memanfaatkan pada wisata pantai namun untuk kesiapan-kesiapan lainnya terkait fasilitas bagi wisatawan masih kurang.

2. Pengembangan Pariwisata Profesional.

Pengelolaan pariwisata secara profesional ditandai dengan pengelolaan wisata yang telah memnuhi berbagai kebutuhan wisatawan. Selain pengelolaan wisata pantai yang juga dilakukan pengelola pariwisata tradisional mereka telah mempersiapkan kebutuhan wisata lainnya seperti: kuliner, penginapan, maupun kebutuhan untuk mengelola kegiatan atau acara yang diperlukan pengunjung atau wisatawan.

Jenis pengembangan wilayah yang dilakukan di atas merupakan hasil wawancara yang dilakukan dengan pihak Pemerintah Kecamatan Pantai Cermin sesuai dengan regulasi yang telah ditentukan. Berkaitan dengan pembahasan hasil penelitian, maka pengembangan pariwisata yang dilakukan di Kecamatan Pantai Cermin menunjukkan adanya 2 (dua) perbedaan dalam pengelolaannya. Selanjutnya juga dapat diketahui bahwa perlakuan terhadap pengembangan yang dilakukan baik secara internal maupun eksternal juga memiliki perbedaan-perbedaan. Sebagai gambaran awal dapat diperkirakan bahwa pengelolaan pengembangan pariwisata yang dilakukan secara tradisional tentu akan tertinggal dalam mempersiapkan aspek yang harus dilengkapi dalam pengembangan pariwisata dibandingkan dengan pengeloaan yang dilakukan secara profesional.

Dasar dalam pengembangan wilayah memerlukan kejelasan letak atau keberadaan dari suatu wilayah yang dilakukan meliputi: 1. Rencana Tata Ruang Wilayah Nasional; 2. Rencana Tata Ruang Wilayah Provinsi; 3. Rencana Tata Ruang Wilayah Kabupaten; 4. Rencana Tata Ruang Wilayah Kota; 5. Rencana Perinci Tata Ruang; 6. Rencana Tata Ruang Kawasan Perkotaan

Sebagai salah satu wilayah potensial maka dalam pengembangan pariwisata, perencanaan wilayah dapat dipahami bahwa pengembangan suatu wilayah tidak berdiri sendiri namun terkait dengan wilayah yang ada di sekitarnya. Berdasarkan hasil penelitian yang dilakukan terdapat keterkaitan antara kebijakan pengembangan dengan kondisi implementasi pengembangan yang dilakukan yaitu:

1. Bahwa implementasi pencapaian rencana strategis yang dilakukan Pemerintah Kabupaten Serdang Bedagai rentan menimbulkan dualisme dalam pelaksanaan pengembangannya. Hal ini dapat diperkirakan karena pengelolaan secara profesional dengan pengelolaan secara tradisional yang dilakukan akan menimbulkan kecenderungan kepada pengeloaan yang dilakukan secara profesional. 
2. Rencana strategis yang dilakukan Pemerintah Kabupaten Serdang Bedagai perlu melakukan pengembangan pariwisata dengan melakukan double standart atau perlakuan yang berbeda terhadap kondisi yang ada. Dalam administrasi publik hal ini disebut dengan perencanaan yang inklusifisme.

3. Dengan adanya perbedaan dalam hal perbedaan pengelolaan dalam pengembangan pariwisata khususnya di Kecamatan Pantai Cermin maka diperlukan pula kesiapan administrasi dalam pelaksanaannya agar dapat terpenuhi aspek keterjangkauan sebagaimana inti dari pelaksanaan pembangunan yang dikemukakan sebelumnya.

4. Dapat melakukan perubahan strategi perencanaan dalam hal pengembangan pariwisata yang dilakukan sesuai dengan tahun berjalan agar rencana perubahan yang dilakukan dapat didukung dengan penganggaran yang cukup.

Perencanaan wilayah yang dilakukan masih bersifat vertikal sehingga dalam penentuan kebijakan mengalami ketidaksesuaian dengan kondisi demografi suatu daerah atau wilayah. Hal ini diperkuat oleh Undang-Undang Nomor 26 Tahun 2007, Tentang Perencanaan Tata Ruang yang melakukan penataan ruang kawasan perdesaan melalui pemerintah kecamatan. Dengan demikian data/informasi yang diperoleh akan melihat berdasarkan kesesuaian kondisi suatu daerah dengan kebijakan yang akan ditetapkan.

\section{Perspektif Kebijakan Publik}

Kebijakan pengembangan pariwisata yang dilakukan di Kecamatan Pantai Cermin merupakan bentuk kebijakan politik (political will) dari Pemerintah Kabupaten Serdang Bedagai sesuai dengan keputusan pemerintah dan Dewan Perwakilan Rakyat Daerah Kabupaten Serdang Bedagai dengan pertimbangan potensi yang dimiliki. Hal ini juga sejalan dengan kebijakan yang dilakukan secara nasional yang menjadikan pariwisata sebagai salah satu prioritas pembangunan nasional. Sektor pariwisata memiliki dampak yang luas terhadap peningkatan kesejahteraan masyarakat karena memiliki banyak ikutan dalam pelaksanaannya. Hal ini menjadi dasar Pemerintah Kabupaten Serdang Bedagai dalam menetapkan Kecamatan Pantai Cermin menjadi kecamatan yang menjalankan pembangunan yang berbasis pada pariwisata.

Evaluasi yang dilakukan dalam penetapan kebijakan Kecamatan Pantai Cermin menjalankan pembangunan yang berbasis pariwisata yaitu: 1). Kebijakan yang dilakukan tidak sepenuhnya memperhatikan aspek internal dan aspek eksternal yang ada pada demografi Kecamatan Pantai Cermin. Kebijakan pengembangan pariwisata yang dimaksud merupakan bagian dari demografi yang harus memperhatikan potensi alam dan potensi budaya dalam arti yang luas. (Nurhadi, 2014).Selain dari faktor demografi, maka faktor lainnya yang juga harus mendapatkan perhatian adalah faktor teknologi informasi yang saat 
ini telah menjadi keniscayaan atau sesuatu yang tidak bisa dihindari.Teknologi informasi yang memasuki seluruh aktivitas kehidupan masyarakat dan seluruh sektor pembangunan yang diselenggarakan pemerintah atau yang lebih dikenal dengan era revolusi industri 4.0. 2). Diperlukan kebijakan yang memberikan keterjangkauan masyarakat luas sehingga akan memberikan dampak terhadap peningkatan kesejahteraan masyarakat. Isu pengusaha profesional dalam menguasai kunjungan wisata memerlukan dukungan dari pihak pemerintah untuk mendukung pengusaha tradisional agar mendapatkan percepatan dalam proses pengembangan pariwisata secara keseluruhan.

\section{Aspek Komunikasi, Kordinasi, dan Disposisi}

Dalam pelaksanaannya pengembangan pariwisata terkait dengan aspek komunikasi serta berbagai aspek lainnya seperti koordinasi, dan disposisi memiliki keterkaitan erat dalam pengembangan pariwisata. Penelitian yang dilakukan menunjukkan komunikasi yang belum berjalan secara maksimal dikarenakan belum adanya unit pelaksana tugas yang jelas di dalam pemerintahan Kecamatan Pantai Cermin dalam menjalankan program pengembangan pariwisata. Meskipun hal ini akan terkait kondisi penganggaran dan sumber daya manusia namun dalam mendukung komunikasi unit tugas di kecamatan yang menjadi perantara antara pihak pemerintah kabupaten dengan masyarakat.

Beberapa hal yang menunjukkan kurangnya komunikasi yang dibangun dalam pengembangan pariwisata adalah sebagai berikut:

1. Pemerintah kecamatan masih kurang dalam membangun sinergitas (kerjasama) yang melibatkan pemerintah kecamatan dan masyarakat dalam mendukung kegiatan (event) dalam mendukung pengembangan pariwisata. Hal ini merupakan salah satu unsur yang harus dilakukan dalam pengembangan pariwisata namun belum berjalan dengan maksimal. Kepala Bidang Pemerintahan Resman Situmorang menyatakan "kegiatan atraksi wisata di Kecamatan Pantai cermin belum ada di agendakan, belum seperti pengembangan pariwisata seperti yang dilaksanakan di Bali, namun pada hari-hari besar tertentu pihak pengusaha hotel atau pengelola pariwisata yang profesional berinisiatif sendiri untuk melaksanakannya".

2. Masyarakat di Kecamatan Pantai Cermin juga menunjukkan kurangnya komunikasi dengan pihak pemerintah dengan kurangnya melakukan penyesuaian atas pekerjaan yang dilakukan masyarakat pada umumnya. Mayoritas masyarakat Pantai Cermin memiliki mata pencaharian sebagai petani sehingga program pengembangan pariwisata yang dijalankan pemerintah Kecamatan Pantai Cermin keterlibatan masyarakat masih kurang. 
3. Kebijakan pemerintah dengan kondisi sosial masyarakat belum sepenuhnya sejalan (connect), hal ini terjadi karena adanya anggapan masyarakat bahwa sektor wisata masih dianggap sebagai alternatif atau pekerjaan sampingan dalam kehidupan masyarakat sehari-hari. Hal ini sangat bertentangan dengan kebijakan pengembangan pariwisata yang ditetapkan di Kecatan Pantai Cermin.

Pengembangan pariwisata di Kecamatan Pantai Cermin merupakan kebijakan yang dilakukan oleh Pemerintah Kabupaten Serdang Bedagai yang dilaksanakan oleh Dinas Pariwisata dan Kebudayaan Serdang Bedagai. Sedangkan kordinasi yang dilakukan masih sangat kurang dikarenakan pemerintah Kecamatan Serdang Bedagai hanya berkordinasi apabila terkait kepentingan birokrasi dari pihak pengelola tempat-tempat wisata namun dalam hal pelaksanaan kegiatan belum diikutsertakan.

Rencana Strategi Pembangunan Daerah Kabupaten Serdang Bedagai yang telah menetapkan Kecamatan Pantai Cermin menjadi kecamatan yang berbasis pariwisata Tahun 2016-2021 menjadi penting untuk melakukan evaluasi rencana strategi yang akan datang. Berdasarkan pembahasan sebelumnya pada bagian perencanaan wilayah bahwa penetapan sebaiknya tidak dilakukan secara top-down tetapi lebih bersifat botton-up dengan mengedepankan kordinasi yang dilakukan pemerintah kecamatan dengan pemerintah desa.

Koordinasi yang dimaksud akan memberikan pengaruh terhadap pemberdayaan masyarakat ke depannya karena telah diawali dengan kesadaran untuk melakukan perencanaan yang sesuai dengan demografi penduduk. (Rusyidi \& Fedryansah, 2019) menyatakan untuk melakukan pemberdayaan masyarakat sangat diperlukan proses perencanaan yang dilakukan secara menyeluruh serta dilakukan mekanisme pemantauan yang berkelanjutan, sistem pengembangan yang sistematik. Hal ini diperlukan agar dapat secara terus menerus merevitalisasi seluruh sumber daya yang ada. Untuk keberlanjutan maka sangat diperlukan pengenalan maupun pemberdayaan yang dilakukan pemerintah kecamatan dengan pemerintah desa.

Penempatan orang-orang dalam pelaksanaan program pengembangan pariwisata di Kecamatan Pantai Cermin berdasarkan hasil wawancara yang dilakukan masih menunjukkan hasil yang kurang maksimal. Hal ini dapat diketahui dengan kurangnya membangun kerjasama dengan berbagai pihak terutama pemerintah Kecamatan Pantai Cermin yang menjadi ujung tombak dalam implementasi suatu kebijakan yang dijalankan. Hal lainnya yang menunjukkan tidak berjalannya pelaksanaan disposisi adalah karena dalam pelaksanaan pengembangan pariwisata yang dilakukan di Kecamatan Pantai Cermin masih didominasi oleh Dinas Pariwisata dan Kebudayaan Kabupaten Serdang Bedagai. 
Sebagaimana hasil wawancara yang dilakukan dengan Sekretaris Kecamatan Pantai Cermin Ibu Dra. Meka Sinaga bahwa "pemerintah Kecamatan Pantai Cermin sebelumnya selalu diajak untuk bekerjasama dalam menjalankan program pengembangan pariwisata, namun pada 3 (tiga) tahun terakhir tidak lagi dilibatkan dalam kegiatan-kegiatan kepariwisataan yang dilakukan". Hal ini menggambarkan bahwa aparatur pemerintah khususnya yang menjalankan tugas di sektor pariwisata belum memiliki pemahaman yang jelas tentang konsep sinergitas atau yang disebut juga konsep Good Governance. Penegasan tentang Good Governance juga ditegaskan sebagai bagian khusus terhadap masyarakat sebagai muara dari pelaksanaan program pembangunan. (Sinaga et al., 2018)

\section{KESIMPULAN}

Implementasi kebijakan pengembangan pariwisata yang dilakukan di Kecamatan Pantai Cermin, Kabupaten Serdang Bedagai belum terkordinasi dengan baik sehingga menghambat upaya pengembangan pariwisata sebagaimana aspek-aspek pengembangan pariwisata yang dilakukan melalui pemberdayaan masyarakat.

Implementasi kebijakan pengembangan pariwisata di Kecamatan Pantai Cermin yang dilakukan melakukan pendekatan pemberdayaan masyarakat sebagaimana konsep Good Governance kurang maksimal karena antara pemerintah kabupaten dengan kecamatan masih berjalan sendiri-sendiri karena kurangnya komunikasi dan kordinasi.

Pengembangan pariwisata sejalan dengan perencanaan suatu wilayah yang menjadi dasar dalam penetapan kebijakan terhadap suatu daerah. Kecamatan Pantai Cermin yang ditetapkan menjadi wisata bahari kurang menyesuaikan dengan realitas demografi karena sebagian masyarakat bekerja sebagai petani bukan nelayan sehingga pemberdayaan masyarakat yang dilakukan memiliki dua tugas sekaligus. Pertama adalah pengembangan pariwisata yang memanfaatkan potensi laut namun juga memberdayakan masyarakat petani untuk ikut berpartisipasi dalam pengembangan pariwisata melalui potensi pertanian yang dimiliki.

Identifikasi dalam partisipasi pengembangan pariwisata sebagaimana konsep pemberdayaan masyarakat melalui hasil penelitian juga sangat terbantu melalui pihak pengusaha pariwisata. Salah satu program pemberdayaaan masyarakat yang dilakukan adalah dengan mempekerjakan para pemuda di Kecamatan Pantai Cermin melalui program casual.

Untuk ke depannya dalam pengembangan pariwisata di Kecamatan Pantai Cermin sangat memerlukan keterlibatan masyarakat agar dapat meningkatkan kesejahteraan masyarakat sebagai tujuan dari pengembangan suatu wilayah. Penelitian tentang pengembangan pariwisata melalui pendekatan efektifitas penyelenggaraan pemerintahan 
juga menjadi hal yang menentukan untuk keberhasilan pengembangan Kecamatan Pantai Cermin. Kordinasi antara pemerintah kabupaten dengan pemerintah kecamatan menjadi hal yang sangat diperlukan agar program yang merupakan visi dari pemerintah kabupaten dapat dicapai.

Perencanaan yang dilakukan dalam pengembangan suatu wilayah juga menjadi dasar keberhasilan suatu program pembangunan. Dengan demikian aspek demografi atau potensi yang dimiliki suatu wilayah menjadi pertimbangan penting dalam menetapkan suatu kebijakan yang melibatkan pihak pemerintah, pihak swasta dan masyarakat.

\section{DAFTAR PUSTAKA}

Charmaz, K., \& Thornberg, R. (2020). The pursuit of quality in grounded theory.

Qualitative Research in Psychology. https://doi.org/10.1080/14780887.2020.1780357

CRESWELL, J. W. (2009). RESEARCH DESIGN Qualitative, Quantitative, and Mixed

Methods Approaches. In SAGE Publications. https://doi.org/10.2307/1523157

Hendrita, V. (2017). KEBIJAKAN PENGEMBANGAN PARIWISATA DI KABUPATEN

TANAH DATAR. Agrifo : Jurnal Agribisnis Universitas Malikussaleh, 2(2).

https://doi.org/10.29103/ag.v2i2.379

Nurhadi, F. (2014). Strategi Pengembangan Pariwisata Oleh Pemerintah Daerah Terhadap

Pendapatan Asli Daerah (PAD) (Studi Pada Dinas Pemuda, Olahraga, Kebudayaan

Dan Pariwisata Kabupaten Mojokerto). Jurnal Administrasi Publik Mahasiswa

Universitas Brawijaya, 2(2). kariamansinaga@dharmawangsa.ac.id

Rusyidi, B., \& Fedryansah, M. (2019). PENGEMBANGAN PARIWISATA BERBASIS

MASYARAKAT. Focus : Jurnal Pekerjaan Sosial, 1(3).

https://doi.org/10.24198/focus.v1i3.20490

Silaban, P., Ginting, P., Rini, E. S., \& Absah, Y. (2017). Marketing analysis of North-

Sumatera tourism an empirical study on satisfaction and sustainable visit of the Asean-

Region tourists. International Journal of Economic Research, 14(8).

Sinaga, K., Lubis, S., Sihombing, M., \& Ritha, M. (2018). Implementation of Tourism 
Destination Development Policy in Samosir Regency.

https://doi.org/10.2991/icoposdev-17.2018.15

Tap MPR No.V/MPR/2000 Tentang Penetapan Visi Indonesia 2020

Undang-Undang Nomor 26 Tahun 2007, Tentang Perencanaan Tata Ruang

Undang-Undang No.32 Tahun 2004 Tentang Otonomi Daerah. 